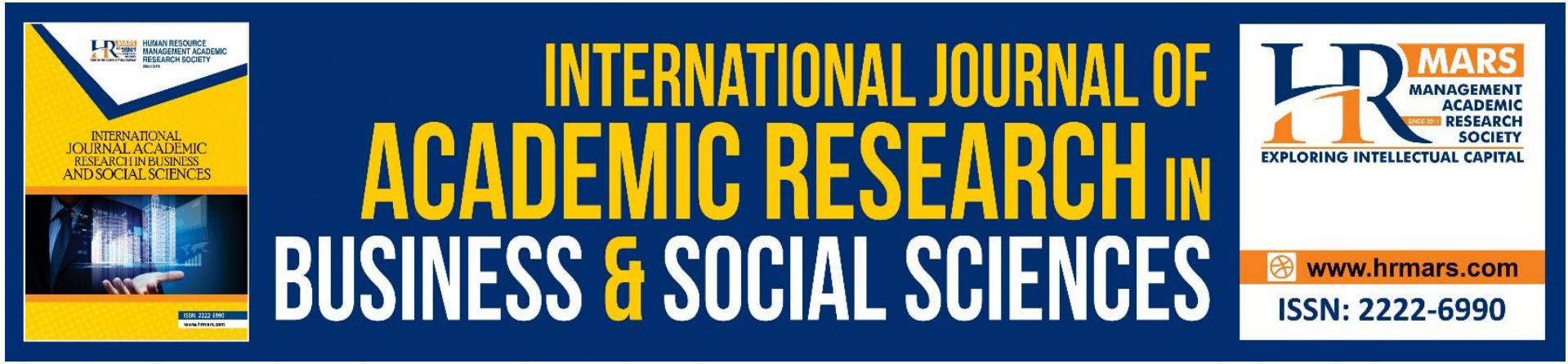

\title{
View of Experts on Knowledge Competency of Higher Order Thinking Skills in The Teaching of Quranic Verses Comprehension
}

Mas Hamidon, Ahmad Johari Sihes, Hanzalah Mohamed Nor

To Link this Article: http://dx.doi.org/10.6007/IJARBSS/v11-i8/10911

DOI:10.6007/IJARBSS/v11-i8/10911

Received: 15 June 2021, Revised: 18 July 2021, Accepted: 09 August 2021

Published Online: 22 August 2021

In-Text Citation: (Hamidon et al., 2021)

To Cite this Article: Hamidon, M., Sihes, A. J., \& Nor, H. M. (2021). View of Experts on Knowledge Competency of Higher Order Thinking Skills in The Teaching of Quranic Verses Comprehension. International Journal of Academic Research in Business and Social Sciences, 11(8), 1969-1983.

Copyright: (c) 2021 The Author(s)

Published by Human Resource Management Academic Research Society (www.hrmars.com)

This article is published under the Creative Commons Attribution (CC BY 4.0) license. Anyone may reproduce, distribute, translate and create derivative works of this article (for both commercial and non-commercial purposes), subject to full attribution to the original publication and authors. The full terms of this license may be seen at: http://creativecommons.org/licences/by/4.0/legalcode

Vol. 11, No. 8, 2021, Pg. 1969 - 1983

Full Terms \& Conditions of access and use can be found at http://hrmars.com/index.php/pages/detail/publication-ethics 


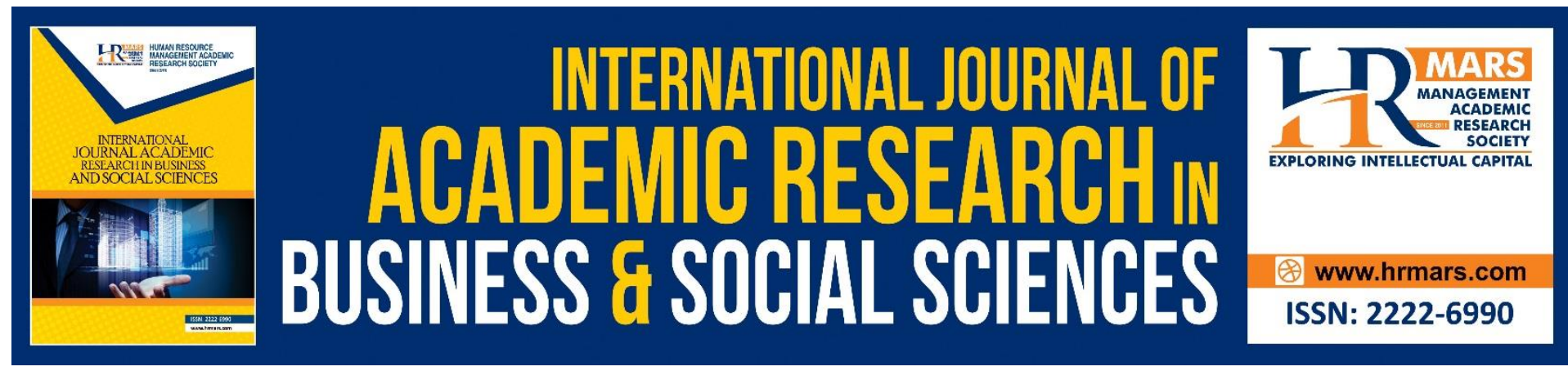

\title{
View of Experts on Knowledge Competency of Higher Order Thinking Skills in The Teaching of Quranic Verses Comprehension
}

\author{
Mas Hamidon ${ }^{1}$, Ahmad Johari Sihes ${ }^{2}$, Hanzalah Mohamed Nor $^{3}$ \\ ${ }^{1}$ Phd Scholar, Faculty of Social Sciences and Humanities, University Technology Malaysia, \\ Johor, ${ }^{2}$ Assoc, Prof, Dr., Faculty of Social Sciences and Humanities, University Technology \\ Malaysia, Johor, ${ }^{3} \mathrm{Phd}$ Scholar, Faculty of Social Sciences and Humanities, University \\ Technology Malaysia, Johor \\ Email: tesisphdutm2019@gmail.com, joha@utm.my,hanzel_nuts07@yahoo.com
}

\begin{abstract}
The teaching of Higher Order Thinking Skills (HOTS) is always applicable when it comes to improve the quality of teaching practices among Islamic Education Teachers. Having said that, this practice is given less importance among the teachers, particularly in the teaching of Quranic verses comprehension. Therefore, this study aims to identify HOTS competency elements needed by Islamic Education Teachers in teaching Quranic verses comprehension from perspective of experts in the related field. The study was conducted qualitatively using semi -structured interview method. A total of six experts were interviewed consisting of three university lecturers, a Curriculum Specialist from the Curriculum Development division and two Head Instructors of secondary school Islamic Education Teachers. All experts were selected through purposive sampling and have fully met all the required criteria. Interview data were analyzed using thematic techniques namely transcription, coding. Additionally themes verbatim were also analysed using atlas ti version 8 . Knowledge Element is the main theme of this study with several other sub-themes namely processes, procedures and metacognitive.
\end{abstract}

Keywords: Higher Order Thinking Skills, Quranic Verses Comprehension, Knowledge, Secondary School Islamic Education Teacher, Islamic Education Experts

\section{Introduction}

Knowledge is one of the key element in the domain of teaching practice competency for Islamic Education Teachers (IET). They need to master Islamic Education as a content knowledge to equip them as creative and effective teachers (Retnawati et al., 2018). Teachers of Islamic Education who fail to master the content knowledge often found it challenging to develop students' thinking skills in the teaching and learning process. Teaching is complex actions that require many types of knowledge. Mastery of knowledge in terms of curriculum, pedagogy and assessment help to change teachers' method of classroom teaching, professional development and achievement (MOE, 2014). Pedagogical knowledge in the implementation of Higher Order Thinking Skills (HOTS) in the teaching and learning process 
should be understood and practiced by all teachers using different teaching methods or strategies to help students proficient in HOTS (Chun \& Abdullah, 2019). Abdullah et al., (2016) and Noh (2017) argued that teachers need to master the knowledge on HOTS learning level through mastery of skills in related knowledge and possess in-depth understanding of the subject content.

Based on al-Ghazali (1939), knowledge is the basis or path to perform pious deeds. It is also the beginning of guidance, the first journey towards Allah. However, pure intention is highly important to pursuit knowledge for the sake of Allah to gain wisdom. Scholars who seek knowledge to fulfill personal goals for the purpose of status, wealth and respect will not be able to understand the essence and spiritual aspects of knowledge. Furthermore, they fail to understand the secrets behind that knowledge, their understanding are limited to external meanings. According to Clark \& Mayer (2007), there are five levels of knowledge identified to enhance teachers' knowledge in HOTS namely facts, concepts, processes, procedures and meta-cognitive. Next, the mastery of high level knowledge involves three stages namely processes, procedures and meta-cognitive.

Education at the global level is changing dynamically from time to time, therefore the knowledge of teaching the Quran needs to be transformative to deal with these changes. The change in teaching of the al-Quran should not focused on Quran recitation alone but need to include understanding of its contents to be realized in daily life. The Quran helps an individual to form strong identity, educate people to embrace high moral values and character, diligence and highly knowledgeable. Understanding the Quran is a gift from Allah that is awarded to those who earnestly study the contents of the Quran (Khalid at el., 2018). Having said that, the practice of reading the Quran along with tadabbur (contemplation) is still given less emphasis whereby al-Quran is commonly recited without further effort to reflect, understand and embrace the real meaning of the Quranic verses (Sin, 2014). Therefore, HOTS approach need to be integrated in Quranic teaching, owing to its importance to relate understanding of the Quran in facing changes that takes place in educational setting.

To relate HOTS approach with the teaching of Quranic verses comprehension, teachers clearly play a major role as the main agent in society that supports higher level of thinking. Hence, teachers need to be competent in all aspects related to HOTS knowledge teaching (Madziah, 2015; Yusoff \& Selman, 2018). Teachers are the main factor that determines the success of HOTS integration compared to other factors. Highlights of earlier works reveal that teachers are the key factor to improve quality of education in most countries (Hu Fan Yang and Neitzel Gil-Flores, 2017; Rodriguez at el., 2019). Therefore, the competence of teachers to implement educational policies does give impact on quality of education. (Saad, Baharuddin \& Ismail, 2017). There are many benefits and advantages of teaching higher level thinking (Ibrahim, Ayub, Yunus \& Mahmud, (2019). HOTS pedagogy can help students to improve their academic achievement through critical thinking (Lee \& Lai, 2017).

Although HOTS is widely discussed in mathematics and science subjects, Islamic Education is also one of the main areas that require HOTS integration. Nevertheless, there are significant differences between Islamic Education subjects and other non-religious subjects. Reasonably, Islamic Education emphasizes knowledge, faith and practice as a complete way of life and human self-development (Al-Nahlawy, 1983; Al-Kaylani, 2005). The aspect of appreciation 
and mastery of knowledge becomes the main core in the Islamic Education system. Thus, the issue of teaching and learning of Quranic verses comprehension using HOTS need to explored from different perspectives. Islamic Education Teachers are the front liners in schools who significantly involved in effective teaching and learning of Quran for students to gain insights and advantages of its content. In brief, the knowledge element of HOTS is relevant to improve the quality of Islamic Education.

\section{Method}

\section{Data Collection Instruments}

This study is a qualitative study through semi -structured individual interviews with experts involved as informants (Cresswell, 2012) They consist of three university lecturers, a curriculum expert and two head instructors. The sample was selected through purposive sampling due to extensive experience of the experts in Quranic studies and HOTS. Semi structured interview questions were constructed based on the study objectives. The interview protocols were developed based on themes identified through literature highlights. To ensure validity of the interview instrument, validation from academic experts with comprehensive understanding and knowledge in the teaching of HOTS is required. Therefore, the interview protocol was presented to two lecturers in qualitative and HOTS areas. Upon validation, researcher of this paper conducted a pilot study to train researchers involved in the field before conducting the actual research. It is also intended to identify any shortcomings and weaknesses in the interview protocol (Merriam, 2009). Interviews were recorded with the consent of the informants and transcribed verbatim. Transcriptions were also validated by all informants in advance before being analyzed, classified and coded (Creswell \& Miller, 2000)

\section{Participants}

A total of six informants were involved in the interviews of this study. The selected informants have more than 20 years of experience in education. Informants in the education field with more than five years of experience in the current field can be classified as experts (Berliner, 2004; Akbari \& Yazdanmehr, 2014). All informants involved in the interview are expertise in certain fields, namely HOTS in Islamic Education in Universities and schools, Quran experts and curriculum experts. All informants in the interview come from different locations, namely Putrajaya, Selangor, Perak and Johor. 
Demographics of the informants are as shown in Table 1.0

Aspect

Experience in

Education

Area of expertise

Work Location

10-15 years
16-20 years
21- 25 years
26 - 30 years
Professor of Islamic Education in university
Associate Professor of HOTS in university
Associate Professor in the field of al-Quran and Tafseer
HOTS Curriculum Specialist in MOE Islamic Education
Head of Instructor in Secondary Islamic Education
Selangor
Perak
Putra Jaya

No

0

0

3

3

1

1

1

1

2

1

2

1

2

\section{Findings}

Based on the verbatim transcript analysis performed, analysis of the interview data has produced codes, categories and themes. Elements of competence Knowledge of HOTS required by Islamic Education Teachers in teaching Quranic verses comprehension from the perspective of Islamic Education Lecturers, Islamic Education Curriculum Specialists and Islamic Education Head Instructors are detailed as follows:

\section{Process}

Process is the first sub-theme of the knowledge element. Some informants agreed that knowledge element for teaching of HOTS in Quranic verses comprehension demands the right process in its implementation. The process is an overview of how a teaching of Qur'an verses comprehension works. This element is confirmed by the following informants:

"Our goal is to teach HOTS, we do not want the students to understand only on the content of a textbook but we want them to relate it with reality, we want to teach them to think ....." (JU/L/01)

P/L/01 further added:

"the HOTS knowledge of IET needs to reach Wisdom because Quran is futuristic... .. ahead of its time....." (P/L/01)

What is more important according to KU/P/01 on the ultimate goal of HOTS teaching is to apply the knowledge and to realize its value in students' lives:

"We have to master knowledge thoroughly. So if we want to relate to Higher Order Thinking Skills, it is not just 'knowing' the knowledge. Their 'higher level of thinking' needs to reach for wisdom. Teachers of Islamic Education not only master the knowledge alone but they have to master knowledge according to al-Ghazali that comprised of 3 things, namely knowledge, skills, and values themselves. Not simply the 
knowledge alone. We want the knowledge, how to implement that knowledge and how its value can be applied." (KU/P/01)

According to (P/L/02), the goal of HOTS in teaching Quranic verses comprehension is to show the truth of Islam and bring students closer to Allah.

"Students need to be creative in creating and solving problem. However, problem solving needs to conform to the truth of Islam. That is the difference of HOTS that we explain to students, which we want to develop the skill of students so that they will be capable to solve their own problems, strengthen their relationship with God and other human beings, and eventually be a selfrighteous person who invite people to do good things. That is what we emphasize in HOTS teaching for Qur'an comprehension subject." (P/L/02)

Thus in the teaching of Quranic verses comprehension, the knowledge element of IET requires broad general knowledge related to the Quranic verses under study. Important element that needs to be emphasized is habitual reading, understanding the Quranic verses not only within Islamic Education context but also across various disciplines. Nevertheless, as teachers know the general goals in HOTS teaching of Quran verses comprehension, the main reference document of Islamic Education Teachers will be the Curriculum and Assessment Standard Document (DSKP) for the construction of objectives, learning outcomes, and focus as mentioned by KU/P/01:

"So, in Quran reading comprehension, what is 'creating minds', that is the knowledge discipline necessary for the teacher to convey to the students. That is the 'level' for the teacher needs to master. Similarly, when we discuss HOTS in Quran verses comprehension, the first thing that the teacher needs to look at is the general objective of Quran verses comprehension. That is, the DSKP that we hold today should be in the hands of teachers every time we write the general objectives, they are actually the objectives contained in the Islamic Education Curriculum Standard Book." (KU/P/01)

$\mathrm{KU} / \mathrm{P} / 01$ further addressed:

"we have to figure out the general objectives of that particular area. How can we come up with general objective of the field, because 'every' objective has been principally set based on 'aqidah. What are the particular objectives in the area of 'aqidah, akhlaq and Quran verses comprehension. If we are discussing on the HOTS element that IET need to master in teaching Quran comprehension subject, first we have to look at the objectives.. So, what are the HOTS element ? The HOTS element here is to practice. When we look at practicing HOTS at this 'level', it is 'the higher level of' HOTS that goes to the 'creative mind' and further goes to action. Along these lines, teaching the subject is not merely listing the lessons of Quranic verses but we go beyond the literal understanding i.e. 'what are we going to do' for us to implement the verse teaching in our daily life. That is the HOTS element that teacher needs to master in teaching this subject." (KU/P/01)

He further addressed that IETs should have a focused knowledge to guide them in teaching the HOTS skills to their students: 
"next to objective is focus. How does focus work in the document? It is actually to guide the teacher to.... provide, supply the necessary skills that students need to master once they have learned the Quranic verses." (KU/P/01)

In short, the mastery of process knowledge requires the right concept in teaching HOTS for Quranic verses comprehension that involves goals, objectives, learning outcomes and focus to produce students who can integrate the demands of fard 'ain and fard kifayah based on Quranic verses learned. Also for them to relate between intellectual knowledge and science based on understanding of the Quranic verses.

\section{Procedure}

The study interviews have obtained some knowledge procedures on HOTS teaching of Quranic verses comprehension from response of the informants in the second sub-theme of knowledge. Procedural knowledge involves a series of step by step actions and decisions designed to accomplish a particular task. Some of the teaching procedures of HOTS in Quranic verses comprehension gathered from the interviews are:

\section{Fluent in Reading the Quran}

IETs need to be fluent in reciting the Quran with accurate tajweed hukm. This is because reading of the Quran without proper tajweed rules will lead to change in meaning

"one of the necessary knowledge related to the content of the Qur'an in terms of reading the Qur'an is correct pronunciation of the letters. The first stage requires the teacher to ensure every letters is pronounced correctly. If Ar-Rahim is pronounced following the tajweed rules, then the meaning is correct. Tajweed do affects the actual meaning." (P/L/03)

\section{Good Command in Arabic Language}

"As for the Quran, the minimum requirement must be Arabic, the minimum.... there must be basic command of Arabic. He knows what is Fi'il, isim, what is a letter, that is the least basic, because the Qur'an was revealed in Arabic." (P/L/03)

"It's best if he understands Arabic language. At least the teacher can read the translation." $(\mathrm{P} / \mathrm{L} / 01)$

\section{Reference to Tafseer Texts and Various Sources}

"..... teachers can certainly refer to tafseer works such as tafseer by Hamka or Qurtubi." $(\mathrm{JU} / \mathrm{P} / 01)$

\section{Basic Knowledge of Tafseer as Explained by Established Tafseer Scholars}

"Teachers can't simply translate based on their personal views. If they wish to contemplate or study particular Quranic verses, they must refer to basics of tafseer as explained by various scholars of tafseer. Only then they can help or propose tafseer reference to their students. The teachers should suggest easily accessible reference to their students." $(\mathrm{P} / \mathrm{L} / 03)$ 


\section{Understand Interpretation of Quranic Verse, Verse by Verse}

"Okay... the aspect of teaching Quranic verses comprehension requires the teachers to interpret the verse one at a time, that is, one verse after another, interpret and continue to relate that particular verse with essence of the verse." ( JU/P/02)

"Teachers who study on interpretation of Quranic verses must refer to the tafseer texts from established Islamic scholars. it is imperative upon them to refer to the tafseer works." (P/L/01)

"A teacher can help or at least make references from various sources, he needs to adhere to the tafseers that have been produced by earlier Islamic scholars. Students need to be assisted by a teacher. Hence the teacher needs to guide the students based on the tafseers, not to rely on literal translation alone." ( $\mathrm{P} / \mathrm{L} / 03)$

The efficiency of interpreting a Quranic verse depends on how IET understands content of the Quran:

"Well, it is easy...the teacher have to read the Qur'an, contemplate and understand the Qur'anic verse carefully." (P/L/01)

\section{Meaning of Each Word and Meaning of the Whole Verse in Quranic Ayah}

Most importantly, P/L/01 GPI highlights on understanding the context of the interpreted verse:

"The person who teaches must understand the context. He has to be aware with the reality and read the verse interpretation. Let's say you read a Quranic verse, what is the verse interpretation? He can't interpret if he understand only on the literal meaning of the verse, word by word. Similarly if we read based on Quran translation, he will not gain full understanding. Therefore, the teacher must first understand the context of the verse." $(\mathrm{P} / \mathrm{L} / 01)$

According to (JU/P/02), IET needs to understand, examine and study the essence of the verse being read.

"The teacher must first understand the meaning of the verse, study its meaning and further study the tafseer texts, to relate the verse with essence of its meaning." (JU/P/02)

\section{Look At Reasons of Revelation (Asbabul Nuzul) to Explain The True Meaning of The Verse}

"To me, Islam has taught me that the future is not just a year, two years, or a century. But it's more towards a longer life. So, a great teacher of Islamic Education, in particular, IET must understand the context of verse and understand the reality because understanding of particular Quranic verse needs to look at reasons of its revelation. If the teachers are experts enough, they will also look from balaghah, grammar, sorof and other related areas. If they can understand the matter, MasyaAllah they will become more expert in this matter." $(\mathrm{P} / \mathrm{L} / \mathrm{O} 1)$

\section{Verse Descriptions and its Relevance To Current Issues}

"Ijaz (inimitability) of al-Quran is very important because if we observe what has been produced, the works on ijaz al-Quran, either earlier or contemporary works, will be very helpful for them to think more deeply about the Quranic. It is not mentioned merely as, *excerpts of 
Quranic verses are read, it is only understood about the camel in physical form, but it is read as what ijaz mentioned in scholar texts of ijaz zul quran on those verses, you need to have knowledge on this.."(P/L/03)

"....... .. as Muslims, the teacher drew lessons from the Quran. Second, how the Quranic verses act as a guide. We can relate the present reality with the Quran. The problem is when we hardly explain the verse because our lack of knowledge, either we fail to understand the Quran or we may not be able to. We fail if we totally do not understand the verses directly, or we are incapable if we lack the knowledge to understand the meaning. How does the teacher relate the verse with what's happening around him. Take the recent case of covid-19 for instance. Literal interpretation of Covid-19 would be regarded as problems of society, problems of the ummah, problems of the country, problems of war, or problems of all kinds." $(\mathrm{P} / \mathrm{L} / 01)$

"So, a person who is capable with a higher level of skills can relate to what is happening today, with any situation given in a plural context and how you relate them with life. Third, if we read about futuring studies, in the west the study is not that far.... but if in Islam the study extends to larger perspective. Futuring study is not merely, for instance adultery, it's not only a surface matter, but the issue goes as far as what happens in the hereafter. So, this requires a level of thinking that.... if he does not read the Quran, does not read the hadith, does not read the views of the scholars, he will reach a dead-end. Why does God forbids adultery?."(P/L/01) "Accordingly, if we know how to contemplate the Quranic verses, that is a real advantage. We can share with the students the deeper meaning, and relate it with other verses, associate it with the story of the prophets, connect them with the story of Rasulullah, and eventually relate the verse with current issues, that is such a great approach. Only then the students will understand why they have to study this verse, otherwise they will not understand." (JU/P/O2)

With reference to the above interview, it can be understood that the element of knowledge involving procedures will improve competency of the teachers. They can organize their content systematically so the content will be interrelated and can be easily understood by students. The content can relate with current issues that revolve around the students' environment.

\section{Metacognitive}

Although metacognitive is not specifically stated by the informants in the interviews, based on the researcher's examination from study literature, there are some informants who highlighted the need for awareness of what is known and what is not known in HOTS teaching, as well as ways to improve the thinking process and learning that takes place. This element was stated by informant (KU/P/01):

\section{Deep Learning About Quranic Verses}

"Now what we want is not simply 'knowledge', we want knowledge and how to implement that knowledge and how its value can be applied. In short, a combination of all that three is what we meant by gaining knowledge. So, as a teacher of Islamic Education, he has to master the method of 'deep learning'." (KU/P/01)

Deep learning is an approach and attitude to teaching and learning, in which the IET thinks meta-cognitively to build long-term understanding. This is a constant influence that has a 
positive impact on the way we act, think or feel. This matter was emphasized again by the informant $(\mathrm{P} / \mathrm{L} / 01)$

"Whatever it is, teacher means knowledge. How deep is your knowledge? Personally, that knowledge needs to be deep. If we don't deepen the knowledge, you can't do it, you can't think, you're only learning on the surface. So, first you need to have the skills, you have to gain lots of knowledge, you have to read a lot, you have to think a lot and you have to think something. Without knowledge, our intellectual is still at low level. For example, if we graduate, we have never read a book, never studied, never read anything etc., and we do not have access to ......... So, our knowledge will... .. From this fundamental point of view, first we should widen our knowledge." (P/L/01)

\section{Deep Understanding}

Deep understanding is related to metacognitive because IETs with high knowledgeable competence will determine what is important for students to learn, remember and focus in teaching HOTS for Quranic verses comprehension as expressed by (P/L/01)

"So, your knowledge is not only about how your feel, but you have to go on certain things, which we come across...., Sometimes our knowledge is, if we are in, for example... ..., let's say we want to relate to the question of thinking skills on ablution for instance. If we think of ablution as one layer, it will be one layer. But if we cross from a scientific point of view, you cross in other fields, so it will relate to health and so on. So, this knowledge will extend. Eventually we can think why? why? why? That would be wise. Because in Islam, Allah asks us to think. So, deep thinking will lead us to more knowledge to be explored." (P/L/O1)

\section{Meaningful Learning}

High metacognitive awareness by IETs will lead to meaningful learning. Meaningful learning is an important cognitive skill that students will use throughout their lives. In the long run, meaningful learning is the most effective method for students to engage in learning. As stated by $\mathrm{KU} / \mathrm{P} / 01$ :

"Through that knowledge, the lessons and learning will turn into 'meaningful learning'. So, those three things are very important to master, not only for the teachers of Islamic Education, but any person who becomes a teacher. There is a difference between opinions of Islamic and secular academics. Secular scholars only mention on knowledge, but in Islam, al-Ghazali mentions not merely knowledge, but we also need to master the three that I mentioned earlier. That is why, when we talk about HOTS, we need to know its meaning. From that meaning, we come up with Curriculum Standard Document. Now 'what is standard? Then they should know how to demonstrate. It's not all about 'knowing'. Once we have the knowledge, how do we apply them as a knowledgeable person to solve life issues."

\section{Teaching Thinking To Bring Wisdom}

IETs with the awareness to improve the thinking process and learning will be wise to interpret to bring wisdom, thus leading students to the concept of ulul albab (people of intellectuals) as stated by the following informants:

"This wisdom comes with... .he has to be smart in interpreting. Wisdom is ability to use knowledge and experience. This wisdom comes with one's skill which is thinking skill. The second wisdom comes with God's permission. There are also people who do not have wisdom, 
they are smart people, but their wisdom is not wise. So, to obtain that wisdom, for me, first you have to ask God for His guidance. Second, once you have asked for guidance, you have to read, you are looking for knowledge. That wisdom, the third is how you see the world. How to see this world as lahwatul Islam, how do we, in the context of ulul - albab. If you ask me about HOTS, its principle follows the concept of ulul albab." (P/L/01)

From the interviews conducted on the experts, it can be summarised that when metacognitive awareness exists, the IETs can control their mind by planning, monitoring and evaluating the teaching and learning process, eventually they gain meaningful learning and wisdom. Metacognitive knowledge helps to enhance learning of the students by guiding them to think, to determine appropriate actions in trying to understand particular situation, to solve problems and to come up with decisions.

\section{Results, Discussion and Recommendations}

The outcomes of this study show that HOTS elements of knowledge competency in the teaching of Quranic verses comprehension as required in secondary school for Islamic Education subjects are implemented according to experts are mainly process, procedure and metacognitive knowledge as shown briefly in Table 1.1. below:

\section{Theme Sub Theme (categories)}

Knowledge 1. Process: IET is knowledgeable in:

- A flow of events

that describes how something works and how to deliver a lesson

- An overview of how HOTS teaching of Quranic verses comprehension works.

\section{Goals}

- The goal of Islamic Education is to produce and form the servants and caliphs of Allah to be knowledgeable, faithful, pious, virtuous and skilled according to the Quran and Sunnah - $\quad$ Contribute towards enhancing the civilization of the nation and country, taking care the well-being of nature for the sake of Allah's blessings both in world and the hereafter.

\section{Objectives:}

- To read Quranic verses fluently with proper tajweed rulings

- To state interpretation of Quranic verses

- To formulate an understanding of selected Quranic verses and practice them in real life

\section{Learning Outcomes:}

- Apply and practice the knowledge of the Qur'an

- $\quad$ Analyze and practice the knowledge of the Qur'an in a respectful manner 
- $\quad$ Assess and practice the knowledge of the

Qur'an in a respectful and steadfast manner

\section{Focus:}

- Science.

- Practical

- $\quad$ Practice

- Appreciation

- Cultivation

\section{Procedure :}

- $\quad$ Procedural

knowledge involves a series of step by step actions and decisions designed for achievement of a particular task.
1. Fluent in reading the Quran

2. Basic command of Arabic language

3. Reference to tafseer texts and various sources

4. Looking at interpretation of Quranic verses, verseby-verse.

5. Understanding the meaning of each word and the meaning of the whole sentence contained in the Quranic verse

6. Looking at reasons of revelation (asbabul nuzul) to explain the true meaning of the Quranic verse

7. Description of Quranic verse and its relevance to current issues

\section{Metacognitive:}

IET is aware of:

- what is known and what is not known in the teaching of HOTS. - ways to enhance the thinking and learning processes that take place.

- When this awareness exists, the IETs will be able to control their mind by planning, monitoring and evaluating the
1. In-depth study of the Quranic verses

(Deep learning)

2. Deep understanding of the Quranic verses (Deep understanding)

3. Meaningful learning

4. Wise interpretation to bring wisdom 
teaching and learning

$(\mathrm{PdP})$ being carried out.

Source: Compiled by author from the interviews.

Competence is the principal characteristic that influences the way Islamic Education Teachers think and act to cope and survive in the long phases of life as a human being. The knowledge element gives a major effect in most jobs. (Koster et al., 2005; Van Hooser, (1998); Hay McBer, 1996). Spencer \& Spencer (1993), highlighted that a highly competent employee should master all knowledge related to his or her specific job. An organization that hires many knowledgeable and skilled employees, will improve the work quality of the workers, hence making the organization more excellent, efficient and highly capable to meet the needs of stakeholders of the organization.

The new normal of current curriculum trends is designed to encourage students to think outside the box while at the same time to think logically, critically and creatively. This trend demands proper knowledge of IETs in dealing with changes of teaching Islamic Education subjects to ensure that continuous learning is taking place actively. Meaning, IETs with HOTS teaching knowledge will be able to produce students who are competent and able to adapt to changes in their environment. A number of researches addressed that IETs are aware of the importance of students to apply HOTS not only within educational setting but also in their real life surroundings. (Ahmad \& Kasim, 2017; Ajmain, Hehsan \& Mohamad, 2019; Ali, Lubis, \& Noh, 2018; Anwar, Saregar, Hasanah \& Widayanti, 2018).

The diversity of HOTS theories, models, modules and teaching strategies of has been widely debated to enhance human thinking ability in education systems around the world. Various interpretations and methods have resulted to clash of understanding between Islam and the West, hence question arises on the real indicators or standard in determining the competence of HOTS Knowledge as an important element in generating structured thinking. (Osman \& Embong, 2020; Othman, 2019). This polemic has created an empty gap in the process of knowledge delivery and practice of teaching Quranic verses to understand the Qur'an in daily practice. The clash of systems opens a new dimension to study, this is because it is important to shape ideal morals of the Muslim individual and solve the life problems ( Marzuki, 2011; Mukhid, 2016; Fitri,2018; Noh, Ajmain \& Rahman, 2017). Therefore, it is a loss to the student if recitation of the Quran is taught without further understanding of its content and value. However, some elements of IETs knowledge need to be integrated with some other elements such as skills and personality.

Hopefully, results of the interviews with selected experts in this study will indirectly help Islamic Education Teachers to empower their knowledge and improve their pedagogical skills for the teaching of Quranic verses comprehension using HOTS approach.

\section{References}

Abdullah, A. H., Mokhtar, M., Abd Halim, N. D., Ali, D. F., Tahir, L. M., \& Kohar, U. H. A. (2016). Mathematics teachers' level of knowledge and practice on the implementation of higher-order thinking skills (HOTS). Eurasia Journal of Mathematics, Science and Technology Education, 13(1), 3-17. 
Ahmad, S. S., \& Kasim, T. S. A. T. (2017). Problems and challenges of Islamic Studies teachers in shaping students' personality and morality: A critical analysis. In Proceedings of the International Conference on Islam, Development and Social Harmony in Southeast Asia (Vol. 283, pp. 1-15)

Ajmain, M. T., Hehsan, A., \& Mohamad, A. M. (2019). Learning and Facilitation (PdPc) Islamic Education in Industrial Revolution 4.0. Journal of Research in Psychology, 1(3), 13-17

Al-Ghazali, (1939). Ihya' Ulum al-Din juz' 1. Mesir: Mutba"ah Mustafa al-Babi al-Halabi.

Ali, M. M., Lubis, M. A., \& Noh, M. A. C. (2018). Keberkesanan Pengajaran Kurikulum Akidah Dalam Pendidikan Islam Berasaskan Kemahiran Berfikir Analitikal Di Sekolah Menengah. Asean Comparative Education Research Journal on Islam and Civilization (Acer-J). Eissn2600- 769x, 2(1), 15-34.

Al-Kaylani, M. A. (2005) Ahdaf al-Tarbiyyah al-Islamiyyah. Dubai: Dar al-Qalam, Emiriah Arab Bersatu

Al-Nahlawy, Abd. Rahman. (1983) Usul altarbiyyah al-islamiyyah wa asalibiha fi al-bait wa almadrasah wa al- mujtama'. Beirut: Dar al-Fikri, Beirut, Lubnan

Akbari, R., \& Yazdanmehr, E. (2014). A Critical Analysis of the Selection Criteria of Expert Teachers in ELT. Theory \& Practice in Language Studies, 4(8).

Anwar, C., Saregar, A., Hasanah, U., \& Widayanti, W. (2018). The Effectiveness of Islamic Religious Education in the Universities: The Effects on the Students' Characters in the Era of Industry 4.0. Tadris: Jurnal Keguruan Dan Ilmu Tarbiyah, 3(1), 77-87.

Berliner, R. (2004). The Near Impossibility Of Testing For Teacher Quality. Education Policy Studies Laboratory. EPSL-0505-110-EPRU

Chun, T. C., \& Abdullah, M. N. L. Y. B. (2019). The teaching of higher order thinking skills (HOTS) in Malaysian schools: Policy and practices. MOJEM: Malaysian Online Journal of Educational Management, 7(3), 1-18.

Clark, R. C., Mayer, R. E. (2007). E-Learning and the Science of Instruction. San Francisco: Pfeiffer

Cresswell, J. W. (2012) Educational Research: Planning, Conducting and Evaluating Quantitative and Qualitative Research (4th ed.). New York: Pearson.

Creswell, J. W., \& Miller, D. L. (2000). Defining validity in qualitative inquiry. Theory into Practice, 39(3), 124-130

Fitri, A. (2018). Pendidikan karakter prespektif al-Quran hadits. TA'LIM: Jurnal Studi Pendidikan Islam, 1(2), 258-287.

Hay/McBer. (1996) Scaled Competency Dictionary. Boston: Hay/McBer

Hu, B. Y., Fan, X., Yang, Y., \& Neitzel, J. (2017). Chinese preschool teachers' knowledge and practice of teacher-child interactions: The mediating role of teachers' beliefs about children. Teaching and Teacher Education, 63, 137-147

Ibrahim, N. N., Ayub, A. F. M., Yunus, A. S. M., \& Mahmud, R. (2019). Effects of Higher Order Thinking Module Approach on Pupils' Performance at Primary Rural School. Malaysian Journal of Mathematical Sciences, 13(2), 211-229.

Khalid, M. N. M., Ab Hamid, H., Khalid, M. F., Hassan, M. A. A., \& Daoh, M. (2018). The Development of Smart Al-Fatihah Game Multimedia Software. Journal of Fatwa Management and Research, 564-579.

Koster, B., Brekelmans, M., Korthagen, F., \& Wubbels, T. (2005). Quality Requirements for Teacher Educators. Teaching and Teacher Education, 21(2), 157-176 
Lee, K. Y., \& Lai, Y. C. (2017). Facilitating higher-order thinking with the flipped classroom model: a student teacher's experience in a Hong Kong secondary school. Research and practice in technology enhanced learning, 12(1), 1-14.

Madziah, A. (2015). Aspek Penilaian dan Pentaksiran Bagi KBAT \& Kemahiran Insaniah. In Seminar, Muzakarah Pakar: Pembentangan Kajian Keberkesanan Pendidikan Islam. IKIM.

Malaysia Education Ministry. (2014), The basic elements of higher order thinking skills (Curriculum). Putrajaya: Curriculum Development Division Malaysia.

Marzuki, M. A. (2011). Pendidikan Al-Quran dan Dasar-dasar Pendidikan Karakter dalam Islam. In Seminar dalam rangka Silaturrahim Wilayah Pendidikan Al-Quran Metode Qiroati (pp. 1-14).

Mayer, R., \& Clark, R. (2011). E-Learning and the Science of Instruction : Proven Guidelines for Consumers and Designers of Multimedia Learning.

Merriam, S. B. (2009). Qualitative Research: A Guide to Design and Implementation (3rd ed). San Francisco, CA: Jossey-Bass

Mukhid, A. (2016). Konsep Pendidikan Karakter Dalam Al-Qur'an. NUANSA: Jurnal Penelitian IImu Sosial dan Keagamaan Islam, 13(2), 309-328.

Noh, M. A. C., Ajmain, M. T., \& Rahman, E. Z. E. A.(2017). Teachers' Practice of Higher Order Thinking Skills in the Lesson of Islamic Education.

Sin, N. Z. M. (2014). Definisi Qawa'id al-Tadabbur: Satu Analisis Perbandingan dengan Qawa'id al-Tafsir. International Journal of Quranic Research, 6(1), 63-82.

Retnawati, H., Djidu, H., Kartianom, A., \& Anazifa, R. D. (2018). Teachers' knowledge about higher-order thinking skills and its learning strategy. Problems of Education in the 21st Century, 76(2), 215.

Rodríguez, G., Pérez, N., Núñez, G., Baños, J., \& Carrió, M. (2019). Developing creative and research skills through an open and interprofessional inquiry-based learning course. 113.

Osman, S. F., \& Embong, W. H. W. (2020). Islamic Education Teacher's Critical Thinking Practice and its Challenges in Enhancing 21 st Century Learning Skills. International Journal of Psychosocial Rehabilitation, 24(05).

Othman, M. S. (2019). Kepentingan Pelaksanaan Pedagogi Pendidikan Islam Melalui Kemahiran Berfikir Aras Tinggi (Kbat) Dapat Memenuhi Aspirasi Falsafah Pendidikan Islam. Jurnal Ulwan, 3(1), 58-69.

Saad, N. M., Baharuddin, J., \& Ismail, S. N. (2017). Hubungan antara tahap kompetensi fungsional guru dengan pencapaian akademik pelajar di sekolah Menengah di Negeri Kelantan. Proceedings of the ICECRS, 1(1).

Spencer, L. M., and Spencer, S. M. (1993). Competence at Work Models for Superior Performance. John Wiley and Sons Inc.United States of America.

Van Hooser, P. (1998). Triangle Of Success. Florida, USA.: Van Hooser Associates, Ocala

Yusoff, W., \& Selman, S. (2018). Teachers' Knowledge of Higher Order Thinking and Questioning Skills: A Case Study at a Primary School in Terengganu, Malaysia. International Journal of Academic Research in Progressive Education \& Development. Retrieved from http://dx. doi. org/10.6007/IJARPED/v7-i2/4120. 